\title{
Clear Cell Carcinoma of the Ovary with Choriocarcinomatous Differentiation- A Rare Aggressive Tumour
}

\author{
Varsha Ginnavaram, Vasugi Gramani Arumugam *, Sandhya Sundaram, Swaminathan Rajendiran, Lawrence D'cruze \\ Department of Pathology, Sri Ramachandra Medical College, Chennai, Tamilnadu, India
}

\author{
DOI: $10.36348 /$ sjpm.2020.v05i03.009 \\ | Received: 29.02.2020 | Accepted: 07.03.2020 | Published: 21.03.2020
}

*Corresponding author: Dr. Vasugi Gramani Arumugam

Abstract

Ovarian surface epithelial tumors with choriocarcinomatous differentiation are vary rare. We report a case of clear cell carcinoma of the ovary with choriocarcinomatous differentiation in a 54-year-old female who got admitted for evaluation of a large pelvic mass. Clinically, mass arising from right adnexa/ soft tissue/ appendix was suspected which on radiologically showed a solid and cystic mass arising from right adnexa. The mass was excised in toto and sent for histopathological examination. Grossly, we received a salphingo-opherectomy specimen measuring $13 \times 11 \times 8 \mathrm{~cm}$. External surface was smooth with congested blood vessels. Cut surface revealed solid (40\%) and cystic (60\%) areas and reddish brown fluid was extruded. Friable and hemorrhagic areas were noted grossly. Microscopy revealed sheets of clear cells the lesion was composed of round to oval cells with ill defined cell border, moderate eosinophilic to clear cytoplasm and bland nuclei. A panel of Immunohistochemical markers were performed and the lesional cells were positive for Pax 8 and beta HCG .With H\&E morphology and Immunohistochemical staining pattern a diagnosis of clear cell carcinoma of the ovary with choriocarcinomatous differentiation was rendered.

Keywords: Choriocarcinomatous differentiation, Pax-8, Beta HCG.

Copyright @ 2020: This is an open-access article distributed under the terms of the Creative Commons Attribution license which permits unrestricted use, distribution, and reproduction in any medium for non-commercial use (NonCommercial, or CC-BY-NC) provided the original author and sources are credited.

\section{INTRODUCTION}

Ovarian carcinomas may produce human chorionic gonadotropin (HCG) or HCG-like substances and may even contain syncytiotrophoblast cells, but a true choriocarcinomatous component has not been described in these tumors.

\section{CASE REPORT}

We report a case of a 54 -year-old woman who presented with weight loss of $10 \mathrm{~kg}$. She attained menopause at the age of 45 years. There was no postmenopausal bleeding. Clinical examination showed an irregular hard pelvic mass extending up to the umbilicus. A computed tomography (CT) showed a heterogeneous irregular mass measuring $14 \times 12 \times 8 \mathrm{~cm}$ in the central pelvic cavity with gross ascites. Radiologically (Fig-1) the mass showed solid and cystic areas and a diagnosis of complex ovarian cyst favouring malignancy was rendered. The mass was excised in toto and sent for histopathological examination. Grossly (Fig-2), we received a salphingo-opherectomy specimen measuring $13 \times 11 \times 8 \mathrm{~cm}$. External surface was smooth with congested blood vessels. Cut surface revealed solid (40\%) and cystic $(60 \%)$ areas and reddish brown fluid was extruded. Friable and hemorrhagic areas were noted grossly. There was no surface involvement by the tumor and no residual normal ovarian or tubal tissue was found. Histologically (Fig-3), the tumor showed sheets of clear cells admixed with giant cells arranged in a solid, glandular, and papillary architecture, and the tumor cells were a combination of clear, eosinophilic, and hobnail cells with grade 3 nuclear features. The giant cells had moderate amount of cytoplasm and hyperchromatic nuclei simulating syncytiotrophoblastic cells. The tumor cells were immunoreactive for Pax8 (Fig-4) and beta HCG. (Fig-5) With H\&E morphology and Immunohistochemical staining pattern a diagnosis of clear cell carcinoma of the ovary with choriocarcinomatous differentiation was rendered.

Table-1: Panel of Immunohistochemical Markers Done

\begin{tabular}{|l|l|}
\hline IHC MARKERS & INFERENCE \\
\hline Pax 8 & Positive in clear cells \\
\hline HCG & $\begin{array}{l}\text { Positive in } \\
\text { sycytiotrophoblast like cells }\end{array}$ \\
\hline
\end{tabular}




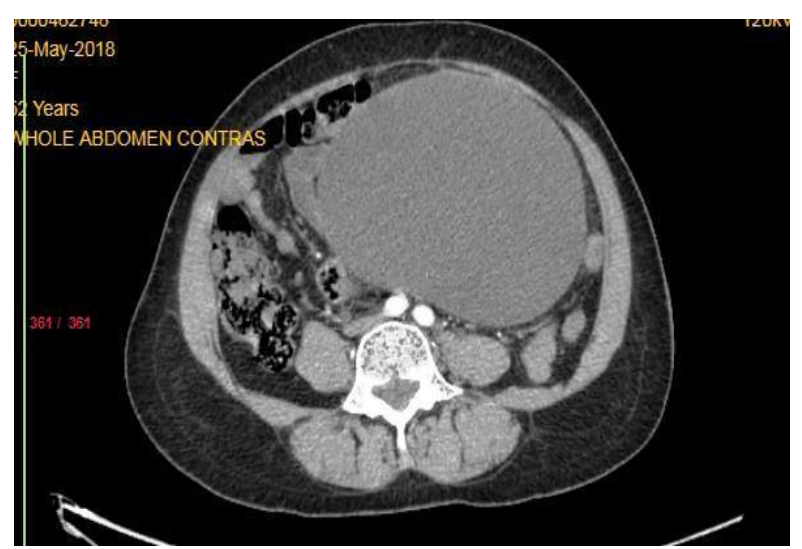

Fig-1: CT pelvis showing solid and cystic mass in right adnexa

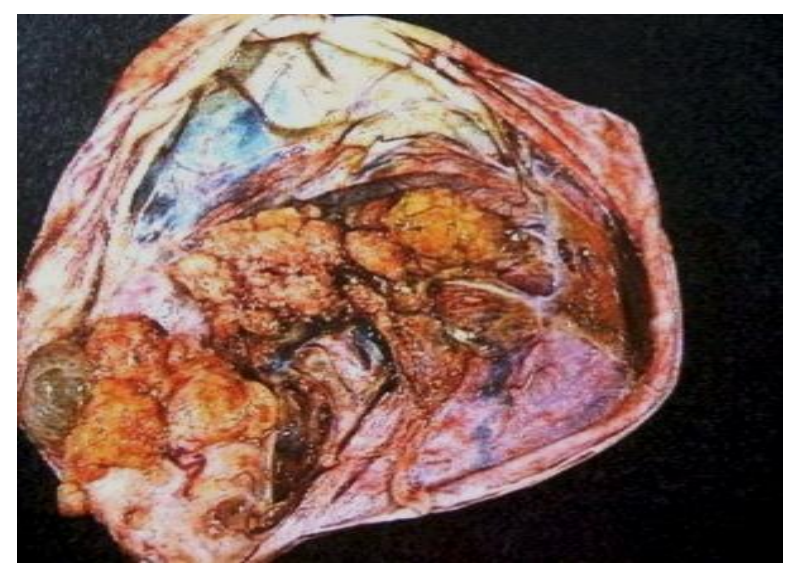

Fig-2: Gross image showing cystic ovarian mass with solid areas $(40 \%)$

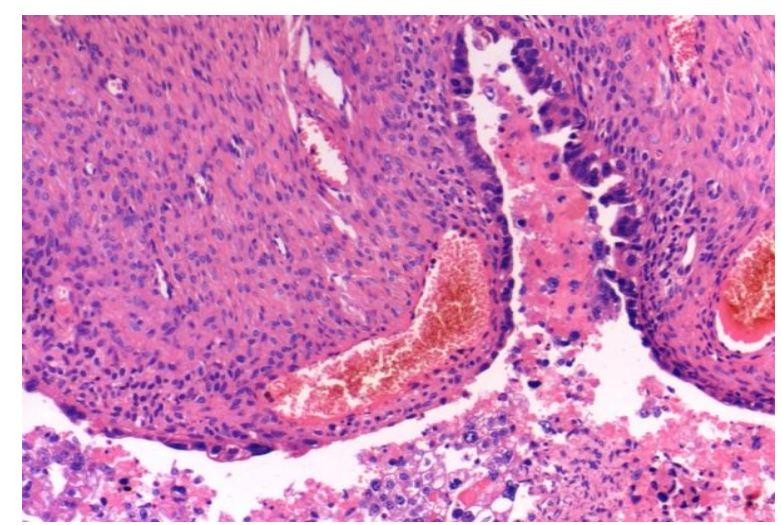

Fig-3a: (H\&E x100)- cystic area lined by atypical clear cells

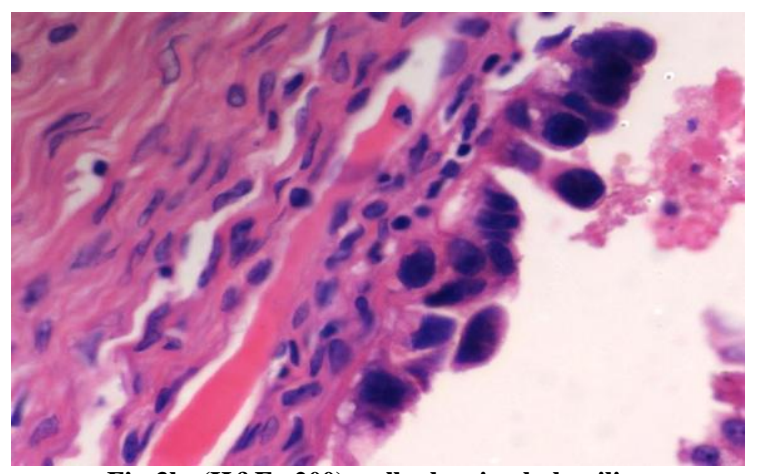

Fig-3b: (H\&E x200)- cells showing hobnailing

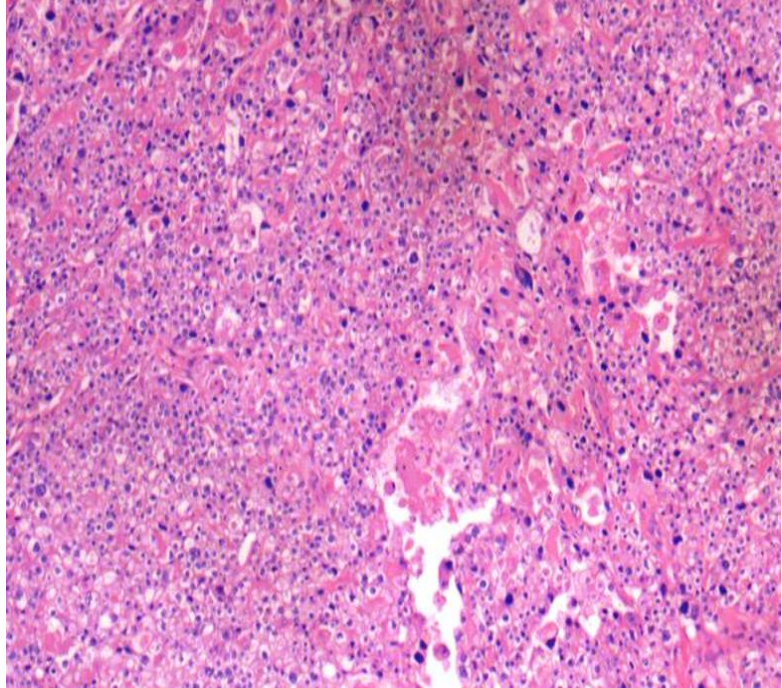

Fig-3c: (H\&E x200)- solid areas showing sheets of clear cells admixed with giant cells simulating syncytiotrophoblast

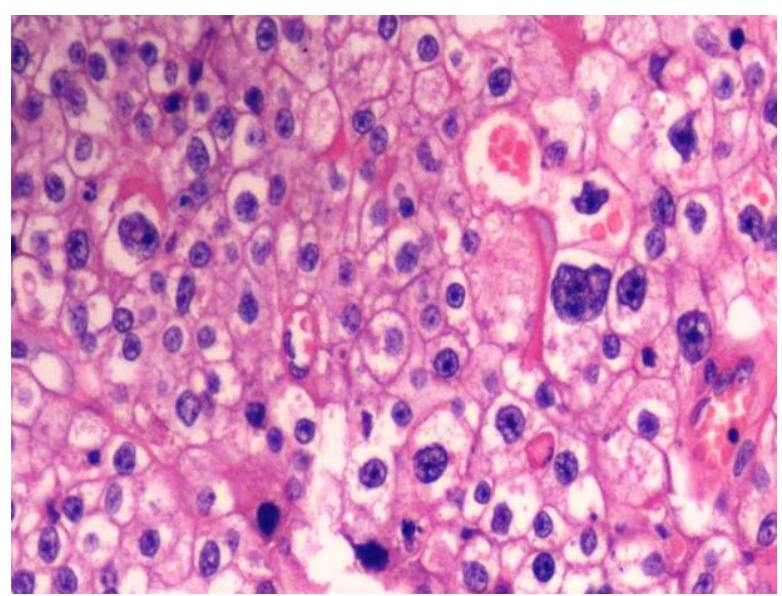

Fig-3d: (x400), solid areas showing sheets of clear cells admixed with giant cells simulating syncytiotrophoblast

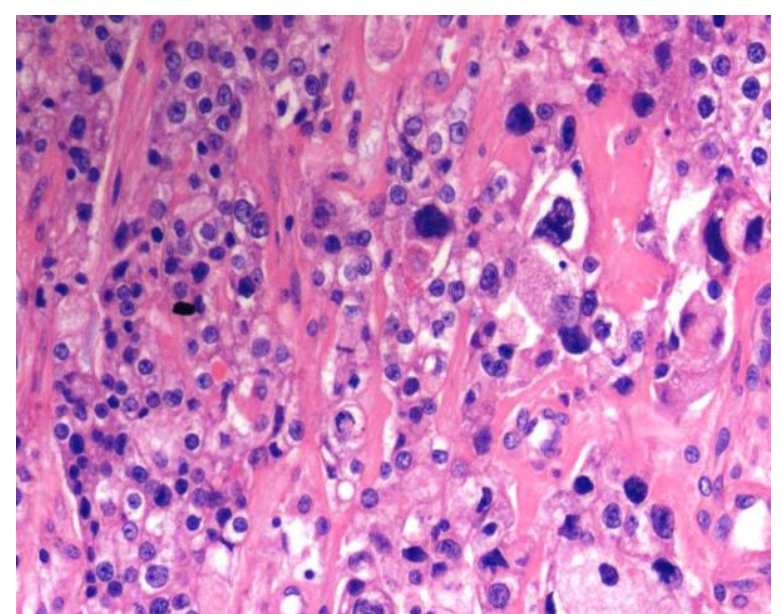

Fig-3e: (x400): solid areas showing sheets of clear cells admixed with giant cells simulating syncytiotrophoblast 


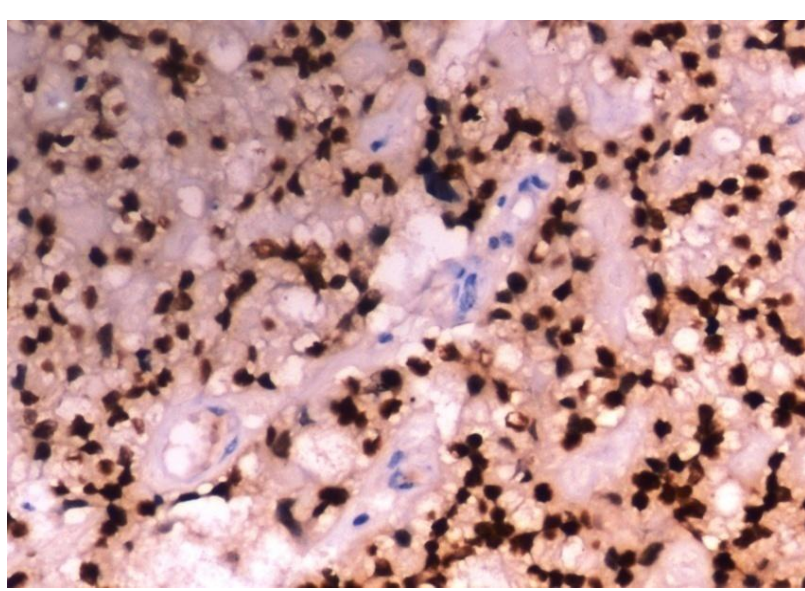

Fig-4: Pax 8 positive staining (IHCx 200)

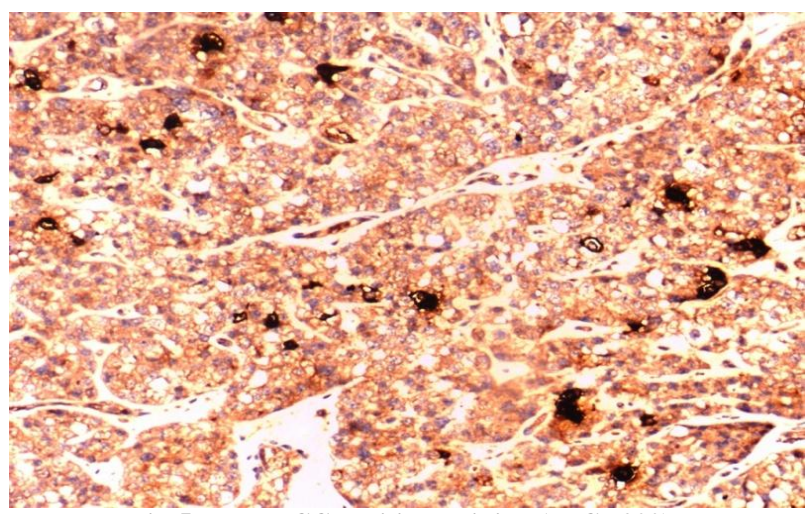

Fig-5: Beta HCG positive staining (IHCx 200)

\section{DISCUSSION}

Choriocarcinoma is a malignant tumor that may present as one end of the spectrum of gestational trophoblastic disease or as a component of a germ cell tumor. Alternately, choriocarcinomatous differentiation has been sporadically described in extragenital tumors, particularly in gastric adenocarcinomas, but in carcinomas from other organs as well, such as lung, esophagus, small bowel, colon, breast, prostate, liver, pelvis, and urinary bladder [1-4]. Carcinomas with trophoblastic differentiation are also rare in the female genital tract.

Civantos and Rywlin [5] and Barua and Richmond [6] respectively, reported three ovarian carcinomas containing anaplastic foci with numerous HCG-positive multinucleated cells and one ovarian carcinosarcoma with isolated trophoblast cells. Various hypotheses have been postulated to explain the histogenesis of this peculiar association. Whereas some authors favor a divergent differentiation [7]" or even a process of "neometaplasia" [8, 9].' the theory of "retrodifferentiation" or "dedifferentiation" appears to be the most acceptable. It attributes this phenomenon to the multipotentiality of the somatic cells, the differentiation of which is a consequence of repression or expression of distinct genes. During carcinogenesis, tumor cells may recuperate morphologic features or functional properties they already had during early embryologic development that are later suppressed under normal conditions [10]. HCG is an oncofetal antigen detectable in fetal tissues as well as in various tumors, with and without SCT cells. It is usually absent in normal adult tissues [11] and its production by tumor cells has been thought to be related to gene "derepression."

An extreme form of trophoblastic differentiation in nongerm cell carcinomas is the development of a true choriocarcinoma in which the malignant cytotrophoblasts and syncytiotrophoblasts grow in a bilaminar or plexiform pattern intermixing with the somatic malignancy. Most choriocarcinomas of the ovary are usually gestational, and are metastases from a uterine or a tubal choriocarcinoma, and rarely as a complication of an ovarian pregnancy. Nongestational choriocarcinomas of the ovary, which are more often a component of mixed germ cell tumors, represented $20 \%$ of such cases in one case series, they are usually found in prepubertal patients.

Pure nongestational choriocarcinomas are exceedingly rare, accounting for less than $1 \%$ of primitive germ cell tumors of the ovary. The presence of choriocarcinoma with a somatic epithelial malignancy of nongerm cell origin is most unusual, with only 5 documented cases found in the literature (Table-1). The age of the patients with ovarian epithelial tumors with choriocarcinomatous differentiation ranged from 33 to 63 years (mean, 51 and median, 51.5). Our patient was also postmenopausal. The presenting complaints were abdominal distention, pelvic mass, pain, or combinations thereof.

The presence of a CC component within an otherwise typical ovarian epithelial tumor results in a very aggressive tumor with early metastasis and highstage disease at presentation as exemplified by this case. Five of the 6 reported cases, including ours, were assigned FIGO stage IV at the time of diagnosis (Table2). All but 1 patient died from the disease between 0 to 15 months (mean, 8.6 and median, 10) after the diagnosis was made. 
Table-2: Similar Case Reports in Literature

\begin{tabular}{|c|c|c|c|}
\hline Reference & $\begin{array}{l}\text { Patient } \\
\text { details }\end{array}$ & Epithelial component & Treatment \\
\hline $\begin{array}{l}\text { Oliva et al., } \\
\text { case } 1 \text { [12] }\end{array}$ & $59 / \mathrm{F}$ & $\begin{array}{l}\text { Undifferentiated } \\
\text { carcinoma }\end{array}$ & $\begin{array}{l}\text { TAHBSO; followed by adjuvant carboplatin, } \\
\text { methotrexate and cyclophosphamide }\end{array}$ \\
\hline $\begin{array}{l}\text { Oliva et al., } \\
\text { case } 2 \text { [12] }\end{array}$ & $33 / \mathrm{F}$ & $\begin{array}{l}\text { No Mucinous } \\
\text { cystadenoma }\end{array}$ & $\begin{array}{l}\text { cisplatin-based chemotherapy; changed to multiagent } \\
\text { chemotherapy (dactinomycin, etoposide, } \\
\text { cyclophosphamide and doxorubicin) for the progressive } \\
\text { disease }\end{array}$ \\
\hline $\begin{array}{l}\text { Ozaki } \\
\text { et al., [13] }\end{array}$ & $53 / \mathrm{F}$ & $\begin{array}{l}\text { Mucinous } \\
\text { cystadenoma }\end{array}$ & TAHBSO \\
\hline $\begin{array}{l}\text { Jimenez-Heffernan } \\
\text { et al., [14] }\end{array}$ & $63 / \mathrm{F}$ & $\begin{array}{l}\text { Mucinous } \\
\text { cystadenocarcinoma }\end{array}$ & $\begin{array}{l}\text { TAH, omentectomy; followed by adjuvant bleomycin, } \\
\text { cisplatin and etoposide }\end{array}$ \\
\hline $\begin{array}{l}\text { Hirabayashi } \\
\text { et al., [15] }\end{array}$ & $50 / \mathrm{F}$ & $\begin{array}{l}\text { Clear cell, small cell, } \\
\text { and endometrioid } \\
\text { adenocarcinoma }\end{array}$ & $\begin{array}{l}\text { TAHRSO, LND; followed by adjuvant cisplatin (IP); } \\
\text { carboplatin \& paclitaxel; changed to EP-EMA for } \\
\text { progressive disease }\end{array}$ \\
\hline $\begin{array}{l}\text { Yuan Jing Hu et al., } \\
\text { [16] }\end{array}$ & $48 / \mathrm{F}$ & $\begin{array}{l}\text { Clear cell } \\
\text { carcinoma }\end{array}$ & $\begin{array}{l}\text { Neoadjuvant etoposide and cisplatin, switched to TE/TC, } \\
\text { followed by TAHBSO, omentectomy and tumor } \\
\begin{array}{l}\text { debulking; and additional TE/TC, } \\
\text { gemcitabine/taxotere }\end{array}\end{array}$ \\
\hline Current case & $54 / \mathrm{F}$ & $\begin{array}{l}\text { Clear cell } \\
\text { carcinoma }\end{array}$ & $\begin{array}{l}\text { Salphingoopherectomy followed by second line } \\
\text { chemotherapy }\end{array}$ \\
\hline
\end{tabular}

\section{CONCLUSION}

In conclusion, we have described the clinicopathologic features of an ovarian clear cell carcinoma with choriocarcinomatous differentiation. Our findings are in keeping with earlier reports, confirming that carcinomas with choriocarcinomatous differentiation behave aggressively. Patients with such tumors are more commonly postmenopausal, have highstage disease at presentation, and poor survival. Nonetheless, our experience with this case suggests that neoadjuvant chemotherapy targeting at both the epithelial and CC components may offer a new treatment option in reducing the volume of the disease and facilitate debulking surgery. Further experience with different chemotherapy regimes is needed before an effective treatment can be determined.

\section{REFERENCES}

1. Wurzel, J., \& Brooks, J. J. (1981). Primary gastric choriocarcinoma: immunohistochemistry, postmortem documentation, and hormonal effects in a postmenopausal female. Cancer, 48(12), 2756-2761.

2. Saigo, P. E., Brigati, D. J., Sternberg, S. S., Rosen, P. P., \& Turnbull, A. D. (1981). Primary gastric choriocarcinoma. An immunohistological study. The American journal of surgical pathology, 5(4), 333-342.

3. Mori, H., Soeda, O., Kamano, T., Tsunekawa, K., Ueda, N., Yoshida, A., \& Fukunishi, R. (1982). Choriocarcinomatous change with immunocytochemically HCG-positive cells in the gastric carcinoma of the males. Virchows Archiv A, 396(2), 141-153.

4. Garcia, R. L., \& Ghali, V. S. (1985). Gastric choriocarcinoma and yolk sac tumor in a man: observations about its possible origin. Human pathology, 16(9), 955-958.

5. Civantos, F., \& Rywlin, A. M. (1972). Carcinomas with trophoblastic differentiation and secretion of chorionic gonadotrophins. Cancer, 29(3), 789798.

6. Barua, R., \& Richmond, D. (1988). Trophoblastic differentiation in a malignant mixed mesodermal tumor of the ovary. Human pathology, 19(10), 1235-1236.

7. Manivel, C., Wick, M. R., \& Dehner, L. P. (1986). Transitional (cylindric) cell carcinoma with endodermal sinus tumor-like features of the nasopharynx and paranasal sinuses. Clinicopathologic and immunohistochemical study of two cases. Archives of pathology \& laboratory medicine, 110(3), 198-202.

8. Pesce, C., Merino, M. J., Chambers, J. T., \& Nogales, F. (1991). Endometrial carcinoma with trophoblastic differentiation. An aggressive form of uterine cancer. Cancer, 68(8), 1799-1802.

9. Lugo, M., \& Putong, P. B. (1984). Metaplasia. An overview. Archives of pathology \& laboratory medicine, 108(3), 185-189.

10. Yoshimoto, T., Higashino, K., Hada, T., Tamura, S., Nakanishi, K., Mitsunobu, M., ... \& Taketa, K. (1987). A primary lung carcinoma producing alpha- fetoprotein, carcinoembryonic antigen, and human chorionic gonadotropin. Immunohistochemical and biochemical studies. Cancer, 60(11), 2744-2750.

11. Haynes, W. D. G., Shertock, K. L., Skinner, J. M., \& Whitehead, R. (1985). The ultrastructural immunohistochemistry of oncofoetal antigens in large bowel carcinomas. Virchows Archiv A, 405(2), 263-275. 
12. Oliva, E., Andrada, E., Pezzica, E., \& Prat, J. (1993). Ovarian carcinomas with choriocarcinomatous differentiation. Cancer, 72(8), 2441-2446.

13. Ozaki, Y., Shindoh, N., Sumi, Y., Kubota, T., \& Katayama, H. (2001). Choriocarcinoma of the ovary associated with mucinous cystadenoma. Radiation medicine, 19(1), 55-59.

14. Jimenez-Heffernan, J. A., Perna, C., Martinez, A., Casinello, J., \& Cuevas, J. (2002). Co-existent ovarian mucinous cystadenocarcinoma and ovarian choriocarcinoma. Archives of gynecology and obstetrics, 266(4), 235-237.
15. Hirabayashi, K., Yasuda, M., Osamura, R. Y., Hirasawa, T., \& Murakami, M. (2006). Ovarian nongestational choriocarcinoma mixed with various epithelial malignancies in association with endometriosis. Gynecologic oncology, 102(1), 111-117.

16. Hu, Y. J., Ip, P. P., Chan, K. K., Tam, K. F., \& Ngan, H. Y. (2010). Ovarian clear cell carcinoma with choriocarcinomatous differentiation: report of a rare and aggressive tumor. International journal of gynecological pathology, 29(6), 539-545. 